\title{
Use of Cryotherapy for Managing Chronic Pain: An Evidence-Based Narrative
}

\author{
Carol Garcia · Jay Karri $\cdot$ Nicholas A. Zacharias $\cdot$ Alaa Abd-Elsayed
}

Received: October 6, 2020 / Accepted: November 19, 2020 / Published online: December 14, 2020

(C) The Author(s) 2020

\begin{abstract}
Background: Cryotherapy has been used to reduce chronic pain for many years due in part to its ease of use, affordability, and simplicity. It can be applied either locally (e.g., ice packs) or non-locally (e.g., partial and whole-body cryotherapy) depending on the location of the pain.
\end{abstract}

Objectives: To determine the overall effectiveness of cryotherapy at reducing chronic pain by characterizing the currently available evidence supporting the use and effects of cryotherapy on chronic pain associated with chronic diseases.

Study Design: A narrative review of original research studies assessing the efficacy of cryotherapy in alleviating chronic pain.

Methods: A PubMed database search was performed to find human studies between the years

C. Garcia · N. A. Zacharias

University of Wisconsin School of Medicine and

Public Health, Madison, WI, USA

J. Karri

Department of Physical Medicine and

Rehabilitation, Baylor College of Medicine,

Houston, TX, USA

A. Abd-Elsayed $(\bowtie)$

Department of Anesthesiology, University of

Wisconsin School of Medicine and Public Health,

Madison, WI, USA

e-mail: alaaawny@hotmail.com
2000 and 2020 that included the application of cryotherapy in patients with chronic pain associated with chronic diseases. A review of the relevant references was also performed to gather more articles. Data was extracted, summarized into tables, and qualitatively analyzed.

Results: Twenty-five studies (22 randomized controlled trials, one prospective analysis, 1 one-group pretest/posttest study, and one case-control study) were included after the literature search. Both local and non-local cryotherapy applications show promise in reducing chronic pain associated with various chronic diseases including those of rheumatic and degenerative origin. Cryotherapy appears to be a safe therapy in carefully selected patients, with only minimal adverse effects reported in the literature.

Limitations: Meta-analysis was not possible given the many differences between studies. Cross-study data homogenization and comparison between studies proved fairly difficult due to the lack of standardized studies, various uses and practice types of cryotherapy, and lack of control groups in some studies.

Conclusions: Local and non-local cryotherapy can be low-risk and easy treatment options to add in the management of chronic pain in carefully selected patients. However, long-term effects, a standardized approach, and careful study of other chronic pain syndromes should be considered in future research to further 
support the use of cryotherapy in the management of chronic pain.

Keywords: Chronic pain; Cold application; Cold therapy; Cryotherapy; Pain

\section{Key Summary Points}

This is a review article discussing the uses of cryotherapy in treating different chronic pain conditions.

Local and non-local cryotherapy can be low-risk and easy treatment options to add in the management of chronic pain in carefully selected patients.

\section{DIGITAL FEATURES}

This article is published with digital features, including a summary slide, to facilitate understanding of the article. To view digital features for this article go to https://doi.org/10.6084/ m9.figshare.13259225.

\section{INTRODUCTION}

Cryotherapy is the superficial application of cold as a therapeutic agent. One of its most common uses is to alleviate chronic pain in specific areas through local application or more broadly through non-local application. Local application involves ice packs/bags, which can be specially designed or be as simple as waterproof plastic bags or frozen vegetable bags. Other local application methods include ice baths, ice massage, gel packs, chemical cold packs, vapocoolant sprays, or specialized cryocuffs that wrap around a joint and circulate cold water [1]. Non-local application of cold includes partial or whole-body cryotherapy. Partial-body cryotherapy excludes the head and neck, involves only one individual, and creates cold by spraying nitrogen gas directly onto the patient's body. Whole-body cryotherapy (WBC) involves a large chamber fitting up to 3-4 patients, creating cold by either combining cooled nitrogen with oxygen and injecting it into the chamber or by circulating nitrogen within the chamber walls [2].

Cryotherapy has been around for ages, being noted in Aphorisms by Hippocrates as a pain reliever for both acute pain like hemorrhage or ankle sprains and its subsequent swelling and chronic pain such as chronic inflammation and joint pain [3]. Since then, physicians have strongly supported the use of cold therapy in alleviating chronic pain. In a 1697 letter to Prince William, Duke of Devonshire, physician John Floyer writes in full support of cold baths as a way to cure and reduce chronic pain associated with rickets and rheumatisms [4]. In an 1846 periodical, a physician wrote in on the benefits he found in his patients with cold water therapy, and one personal account notes the cure of their rheumatism and associated pain from cold therapy [5]. Physicians and physical therapists today still commonly prescribe cryotherapy as a way to reduce chronic aches and pains, especially due to the ease of use, simplicity, and low cost of this kind of therapy. However, while the use of cryotherapy in reducing chronic pain is very common, the exact mechanism and effectiveness still remains unknown.

In this paper, we aim to evaluate the effect of cryotherapy on chronic pain by reviewing the literature on both whole-body cryotherapy (WBC) and local cryotherapy (LC) on chronic pain caused by chronic diseases. We will first explain the proposed mechanism of action of cold therapy, then explain patient selection, and lastly explore the evidence and literature on benefits and adverse effects of cryotherapy.

\section{METHODS}

An online literature search was performed using the PubMed database on the use of cryotherapy in chronic pain. The following terms were used to perform the search: cryotherapy, cold therapy, cold application, chronic pain, and pain. The search was limited to the English language, 
human studies, randomized controlled trials, clinical trials, and systematic reviews with results by year narrowed down from 2000 to 2020. A review of relevant references was also performed to gather additional articles. Studies focusing on acute trauma pain, post-operative pain, cryotherapy on healthy subjects (sometimes referred to as cryostimulation), and the use of cryoneurolysis or alternating heat and cold therapy were excluded, while those involving patients with chronic diseases that lead to chronic pain and/or had a detrimental effect on daily living were included. This article is based on previously conducted studies and does not contain any studies with human participants or animals performed by any of the authors.

\section{CRYOTHERAPY MECHANISM OF ACTION}

Although the mechanism of action of pain reduction by cryotherapy remains uncertain, there are a few primary theories that exist: reduction in inflammation/edema, oxidative stress, and nerve transmission in pain fibers.

\section{Inflammation/Edema}

Chronic inflammation can contribute to constant pain by chemical and mechanical stimulation of pain receptors and free nerve endings [6], which commonly occurs in autoimmune disease such as rheumatoid arthritis, ankylosing spondylitis, and multiple sclerosis. Thus, there is a strong interest in using cryotherapy to reduce inflammation in these chronic pain syndromes to hopefully also reduce the subsequent pain.

Edema and cytokines are key inflammatory markers used to assess the effects of treatments on inflammation. Edema is a cardinal sign of inflammation, caused by vascular changes and increased permeability that allows fluid to enter the extravascular space. The increased pressure in this space often leads to mechanical stimulation and pain production [6]. Cryotherapy is thought to decrease swelling [7] by a combination of decreasing vascular permeability [8] and reducing both arterial and soft tissue blood flow to the affected areas [9].

Cytokines are key regulators of the immune system that can work to maintain homeostasis, but also play an important role in driving inflammatory responses. In general, cytokines such as IL-1, TNF- $\alpha$, IL-6, IL-12, and IL-17 are considered pro-inflammatory, while cytokine IL-10 is considered anti-inflammatory [10]. Studies have suggested that cryotherapy decreases inflammation by decreasing pro-inflammatory cytokine TNF- $\alpha$ [11-13], increasing anti-inflammatory cytokine IL-10 [14], and contrary to expectations, increasing pro-inflammatory cytokine IL-6 [11, 14-16]. However, new evidence suggests that IL- 6 may also possess anti-inflammatory properties [17, 18]. In agreement, Straub et al. found an increase in IL6 in patients with rheumatoid arthritis after WBC, with that group demonstrating the best clinical outcome as measured by swollen joint count and pain scores [16].

\section{Nerve Transmission in Pain Fibers}

Another proposed mechanism of cryotherapy is reducing nerve transmission velocity in pain fibers [1], which may be a way that cryotherapy induces an analgesic effect and pain relief. Previous literature concluded that cryotherapy significantly reduced both motor and sensory nerve conduction velocity [19]. Algalfy and George found decreased nerve conduction velocity at the site of cryotherapy application, as well as increased pain threshold and tolerance. Of note, the effect on pain threshold and tolerance also extended distally to an area beyond the site of application, but supplied by the same nerve [20].

\section{Oxidative Stress}

Oxidative stress has been associated with many human diseases including but not limited to cardiovascular diseases, neurodegenerative diseases, cancer, and rheumatoid arthritis. Oxidative stress can be a pathologic hallmark of autoimmune diseases, leading to more 
inflammation and adding to the constant pain a patient is in [21]. Studies have shown that cryotherapy may reduce oxidative stress by increasing total antioxidant status (TAS) $[22,23]$ and ferric reducing ability of plasma (FRAP), which is another way of measuring overall antioxidant status [24]. Additionally, research suggests that cryotherapy decreases total oxidant status (TOS) and oxidative status index (OSI), which is a ratio of TOS to TAS, as well $[22,24,25]$.

\section{PATIENT SELECTION}

As mentioned earlier, cryotherapy has been used to alleviate both acute and chronic pain. Acute pain is commonly associated with injury, infection, or disease, and is often easier to treat and relieve compared to chronic pain, which may not be associated with a physical injury. The most common mechanisms leading to chronic pain are mechanical or chemical irritation, nerve regeneration, motor reflexes, or inhibitory failure. Pain is usually considered to be chronic when it has persisted for longer than 3 months, lacks a correctable or identifiable cause, and medical treatments have not provided relief [6].

In this paper, the studies selected for the review involved chronic conditions that produced persistent pain. We divided the studies into three groups: rheumatic diseases, degenerative diseases, or a broad group of diseases under the name "other." This was done because rheumatic diseases have underlying pathologies of dysregulated inflammation, whereas degenerative diseases have structural pathologies, which may or may not be accompanied with underlying inflammation. The rheumatic disease group consists of patients with psoriatic arthritis, rheumatoid arthritis (RA), gouty arthritis, and ankylosing spondylitis (AS), the degenerative disease group consists of patients with osteoarthritis (OA), chronic low back pain, adhesive capsulitis, musculoskeletal diseases, and myofascial pain syndrome, and the other group consisted of patients with chronic venous disease, fibromyalgia (FM), and multiple sclerosis (MS).
Cryotherapy is not safe for everyone and precautions must be taken. There is always a possibility of frost bite with exposures to very cold temperatures, especially with certain local cryotherapy applications such as ice massage or cold packs, that are left on for more than 20 min [1]. Whole-body cryotherapy also poses a risk of frost bite if precautions such as using gloves and hats and moving the fingers are not taken [2]. Another adverse effect is cold urticaria, which may have a small local reaction consisting of itching and red swellings to large, systemic effects such as facial flushing, hypotension, tachycardia, and syncope [6]. Cryotherapy is also contraindicated in patients with cryoglobulinemia, Raynaud's disease, paroxysmal cold hemoglobinuria, peripheral vascular diseases, or insensate skin $[1,6,26]$, so proper screening questions are essential prior to recommending cold therapy.

\section{SUPPORTIVE EVIDENCE ON PAIN REDUCTION AND ADVERSE EFFECTS}

Chronic pain is a multidimensional experience, and it is important to focus not only on pain measurements, but also on range of motion and function in order to determine cryotherapy's overall impact on chronic pain [27]. Chronic pain can limit range of motion and decrease function of the affected area by increasing pain with movement [6]. For this reason, the outcomes in this review will primarily focus on pain measurements, such as the Visual Analogue Scale for pain (VAS), with supplementary evidence including range of motion (ROM) and disease activity, such as Bath Ankylosing Spondylitis Disease Activity Index (BASDAI) and Disease Activity Score 28 (DAS28) among a few others. For example, the BASDAI has six questions for patients with AS regarding fatigue, spinal and peripheral joint pain, peripheral swelling, tenderness, and morning stiffness [28] and the DAS28 includes parameters such as swollen and tender joint count, global visual analogue scale measuring overall patient health, and erythrocyte sedimentation rate $[13,29]$. With these disease activity scores, a 
more generalized conclusion can be made as chronic pain can affect almost every aspect of a patient's life.

Figure 1 illustrates a flow diagram of the literature search and study selection, as adapted from Preferred Reporting Items for Systematic Reviews and Meta-Analysis (PRIMSA) [30], which lead to the 25 studies included in this review. The studies consisted of 22 randomized controlled trials, one prospective analysis, 1 one-group pretest/posttest study, and one case-control study.

\section{Rheumatic Diseases}

Multiple studies have looked at the effect of cryotherapy on chronic pain caused by rheumatic diseases (Table 1). As mentioned earlier, chronic inflammation, which is present in chronic rheumatic conditions such as rheumatoid arthritis (RA) and ankylosing spondylitis (AS), can lead to persistent pain that often affects the joints [6]. WBC has been extensively studied in patients with AS. Stanek et al. reported in two different studies a significantly reduced mean pain (VAS) score following WBC at $-120^{\circ} \mathrm{C}$ and rehab, along with a significantly greater reduction compared to the control group with just rehab [28, 31]. Stanek et al. also reported in two additional studies a significant decrease in disease activity as measured by BASDAI, and the WBC $\left(-120^{\circ} \mathrm{C}\right)$ and rehab groups had a significantly greater reduction in BASDAI than the control groups that just received rehab $[24,32]$. A decrease in BASDAI was also reported by Straburzynska-Lupa et al. in all their study groups (WBC at
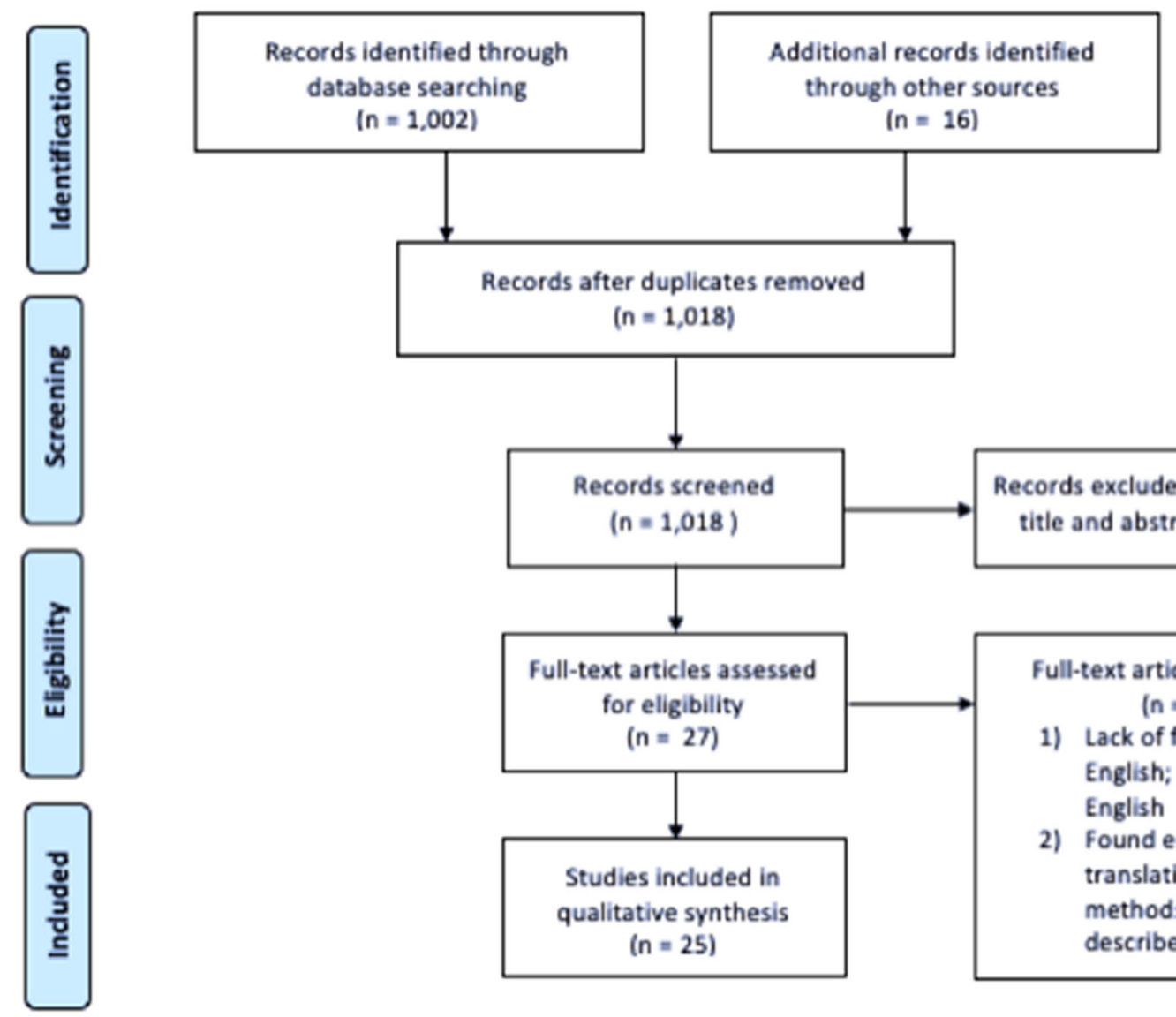

Records excluded after reading title and abstract $(n=991$ )

Fig. 1 Flow diagram adapted from PRIMSA, documenting the process of the literature search [30] 
Table 1 Rheumatic diseases

\begin{tabular}{|c|c|c|c|c|c|}
\hline Author, date & Study design & Study population & Intervention & Outcomes & Complications \\
\hline $\begin{array}{l}\text { Gizińska et al., } \\
2015 \text { [12] }\end{array}$ & Randomized & $\begin{array}{l}\text { RA (women) } \\
N=25 \\
\text { WBC + rehab } \\
N=19 \text { control } \\
\text { (rehab) }\end{array}$ & $\begin{array}{l}\text { WBC at } \\
-110{ }^{\circ} \mathrm{C} \text { for } \\
3 \text { min } 1 \times \text { a } \\
\text { day, } 2 \text { weeks }\end{array}$ & $\begin{array}{l}\text { Pain reduction: WBC } \\
\text { and control groups } \\
\text { had decreased mean } \\
\text { pain VAS by } \\
1.08 \mathrm{~cm} \text { and } \\
1.11 \mathrm{~cm} \text {, } \\
\text { respectively (no } \\
\text { significant } \\
\text { difference b/w } \\
\text { groups) } \\
\text { Inflammation: WBC } \\
\text { decreased IL-6 and } \\
\text { TNF- } \alpha\end{array}$ & None reported \\
\hline $\begin{array}{l}\text { Schlesinger } \\
\text { et al., } 2002 \\
{[36]}\end{array}$ & Randomized & $\begin{array}{l}\text { Gouty arthritis } \\
N=10 \mathrm{LC} \\
N=9 \text { control }\end{array}$ & $\begin{array}{l}\text { LC (ice pack) for } \\
20 \text { min } 4 \times \text { a } \\
\text { day, } 1 \text { week }\end{array}$ & $\begin{array}{l}\text { Pain reduction: WBC } \\
\text { decreased mean } \\
\text { pain VAS by } \\
7.75 \mathrm{~cm} \text { compared } \\
\text { to } 4.42 \mathrm{~cm} \text { in the } \\
\text { control group } \\
\text { (significant } \\
\text { difference b/w } \\
\text { groups) }\end{array}$ & None reported \\
\hline $\begin{array}{l}\text { Straub et al., } \\
2009 \text { [16] }\end{array}$ & Randomized & 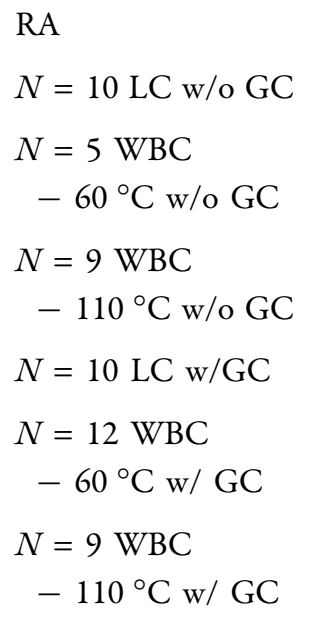 & $\begin{array}{l}\text { WBC at } \\
-110{ }^{\circ} \mathrm{C} \text { or } \\
-60{ }^{\circ} \mathrm{C} \text { for } \\
2 \text { min } 2-3 \times \text { a } \\
\text { day, } 1 \text { week } \\
\text { LC b/w }-20 \text { and } \\
-30{ }^{\circ} \mathrm{C} \text { for } \\
10-30 \text { min } \\
2-3 \times \text { a day, } \\
1 \text { week }\end{array}$ & $\begin{array}{l}\text { Pain reduction: WBC } \\
\text { at }-110^{\circ} \mathrm{C} \\
\text { decreased pain VAS } \\
\text { in groups w/ and } \\
\text { w/o GC } \\
\text { Inflammation: WBC } \\
\text { at }-110^{\circ} \mathrm{C} \text { in } \\
\text { group w/o GC had } \\
\text { IL-6 increase and } \\
\text { swollen joint count } \\
\text { decrease }\end{array}$ & None reported \\
\hline
\end{tabular}


Table 1 continued

\begin{tabular}{|c|c|c|c|c|c|}
\hline Author, date & Study design & Study population & Intervention & Outcomes & Complications \\
\hline $\begin{array}{l}\text { Hirvonen } \\
\text { et al., } 2006 \\
\text { [34] }\end{array}$ & $\begin{array}{l}\text { Randomized, } \\
\text { single- } \\
\text { blinded }\end{array}$ & $\begin{array}{l}\mathrm{RA} \\
N=20 \mathrm{WBC} \\
\quad-110^{\circ} \mathrm{C}+\text { rehab } \\
N=17 \mathrm{WBC} \\
\quad-60^{\circ} \mathrm{C}+\text { rehab } \\
N=17 \mathrm{LC}+\text { rehab }\end{array}$ & $\begin{array}{l}\text { WBC at } \\
-110^{\circ} \mathrm{C} \text { or } \\
-60{ }^{\circ} \mathrm{C} \\
2-3 \times \text { a day, } \\
1 \text { week } \\
\text { LC (cold pack, } \\
\text { cold air at } \\
\left.-30{ }^{\circ} \mathrm{C}\right) \\
2-3 \times \text { a day, } \\
1 \text { week }\end{array}$ & $\begin{array}{l}\text { Pain reduction: LC } \\
\text { and WBC at } \\
-110^{\circ} \mathrm{C} \\
\text { significantly } \\
\text { decreased VAS pain } \\
\text { by } 1.1 \mathrm{~cm} \text { and } \\
2.4 \mathrm{~cm} \text {, respectively; } \\
\text { WBC at }-110^{\circ} \mathrm{C} \\
\text { significantly } \\
\text { decreased more } \\
\text { than the LC and } \\
\text { WBC at }-60{ }^{\circ} \mathrm{C} \\
\text { groups } \\
\text { Disease activity: } \\
\text { decrease in DAS in } \\
\text { all groups }\end{array}$ & $\begin{array}{l}\text { LC: respiratory } \\
\text { infection (2), frost } \\
\text { bite (1), joint or } \\
\text { muscle pain (1) } \\
-60{ }^{\circ} \mathrm{C} \text { WBC: } \\
\text { headache (1), } \\
\text { hypertension (1), } \\
\text { dizziness (1), } \\
\text { malaise (2), joint } \\
\text { or muscle pain (1), } \\
\text { nervousness (1) } \\
-110{ }^{\circ} \mathrm{C} \text { WBC: } \\
\text { respiratory } \\
\text { infection (1), } \\
\text { hypertension (1), } \\
\text { urticaria (1), long } \\
\text { lasting freezing (2), } \\
\text { malaise (1) }\end{array}$ \\
\hline $\begin{array}{l}\text { Jastrzabek } \\
\text { et al., } 2013 \\
\text { [13] }\end{array}$ & Randomized & $\begin{array}{l}\mathrm{RA} \\
N=20 \mathrm{LC} \\
\quad-160^{\circ} \mathrm{C} \\
N=20 \mathrm{LC} \\
-30^{\circ} \mathrm{C}\end{array}$ & $\begin{array}{l}\text { LC at }-160^{\circ} \mathrm{C} \\
\text { with liquid } \\
\text { nitrogen flow or } \\
-30^{\circ} \mathrm{C} \text { with } \\
\text { cold air flow for } \\
30 \text { min } 2 \times \text { a } \\
\text { day, } 10 \text { days }\end{array}$ & $\begin{array}{l}\text { Pain reduction: } \\
-160^{\circ} \mathrm{C} \text { and } \\
-30{ }^{\circ} \mathrm{C} \text { LC } \\
\text { decreased pain VAS } \\
\text { by } 3.34 \mathrm{~cm} \text { and } \\
2.69 \mathrm{~cm} \text {, } \\
\text { respectively } \\
\text { Disease activity: } \\
\text { Increased ROM and } \\
\text { improvements in } \\
50 \text {-m walk test in } \\
\text { both groups } \\
\text { Inflammation: both } \\
\text { LC groups } \\
\text { decreased TNF- } \alpha \text {, } \\
\text { no change found in } \\
\text { IL- } 6\end{array}$ & None reported \\
\hline
\end{tabular}


Table 1 continued

\begin{tabular}{|c|c|c|c|c|c|}
\hline Author, date & Study design & Study population & Intervention & Outcomes & Complications \\
\hline $\begin{array}{l}\text { Sadura- } \\
\text { Sieklucka } \\
\text { et al., } 2019 \\
\text { [29] }\end{array}$ & Randomized & $\begin{array}{l}\text { RA } \\
N=25 \\
\text { WBC + rehab } \\
N=25 \text { control } \\
\quad \text { (rehab) }\end{array}$ & $\begin{array}{l}\text { WBC at } \\
-120^{\circ} \mathrm{C} \text { to } \\
-140{ }^{\circ} \mathrm{C} \text { for } \\
2 \text { min } 1 \times \text { a } \\
\text { day, } 20 \text { days }\end{array}$ & $\begin{array}{l}\text { Pain reduction: WBC } \\
\text { and control groups } \\
\text { decreased VAS } \\
\text { morning pain } \\
(1.2 \mathrm{~cm}, 1.9 \mathrm{~cm}) \text {, } \\
\text { VAS activities of } \\
\text { daily living pain } \\
(1.6 \mathrm{~cm}, 1.8 \mathrm{~cm}) \text {, } \\
\text { VAS night pain } \\
(1.2 \mathrm{~cm}, 2.1 \mathrm{~cm}) \\
(\text { no significant } \\
\text { difference b/w } \\
\text { groups) } \\
\text { Inflammation: no } \\
\text { changes in IL- } 6, \mathrm{IL}- \\
10 \text {, and TNF- } \alpha\end{array}$ & None reported \\
\hline $\begin{array}{l}\text { Stanek et al., } \\
2015 \text { [28] }\end{array}$ & Randomized & $\begin{array}{l}\text { AS } \\
N=32 \\
\text { WBC }+ \text { rehab } \\
N=16 \text { control } \\
\text { (rehab) }\end{array}$ & $\begin{array}{l}\text { WBC at } \\
-120{ }^{\circ} \mathrm{C} \text { for } \\
3 \text { min } 1 \times \text { a } \\
\text { day, } 10 \text { days }\end{array}$ & $\begin{array}{l}\text { Pain reduction: WBC } \\
\text { and the control } \\
\text { decreased VAS pain } \\
\text { by } 2.48 \mathrm{~cm} \text { and } \\
0.91 \mathrm{~cm} \text {, } \\
\text { respectively } \\
\text { (significant } \\
\text { difference b/w } \\
\text { groups) }\end{array}$ & $\begin{array}{l}\text { Slight aggravation of } \\
\text { symptoms in the } \\
\text { beginning days of } \\
\text { treatment }\end{array}$ \\
\hline $\begin{array}{c}\text { Hinkka et al., } \\
2017 \text { [35] }\end{array}$ & $\begin{array}{l}\text { Randomized, } \\
\text { crossover }\end{array}$ & $\begin{array}{l}\text { Inflammatory } \\
\text { arthritis (RA, AS, } \\
\text { Psoriatic arthritis) } \\
N=121 \text { WBC }\end{array}$ & $\begin{array}{l}\text { WBC for } 2 \text { min } \\
2 \times \text { a day, } \\
1 \text { week }\end{array}$ & $\begin{array}{l}\text { Pain reduction: WBC } \\
\text { group had a } \\
\text { significantly greater } \\
\text { reduction in VAS } \\
\text { pain compared to } \\
\text { control group at } \\
\text { the end of the } \\
\text { treatment week }\end{array}$ & None reported \\
\hline
\end{tabular}


Table 1 continued

\begin{tabular}{|c|c|c|c|c|c|}
\hline Author, date & Study design & Study population & Intervention & Outcomes & Complications \\
\hline $\begin{array}{l}\text { Straburzynska- } \\
\text { Lupa et al., } \\
2018 \text { [33] }\end{array}$ & Randomized & 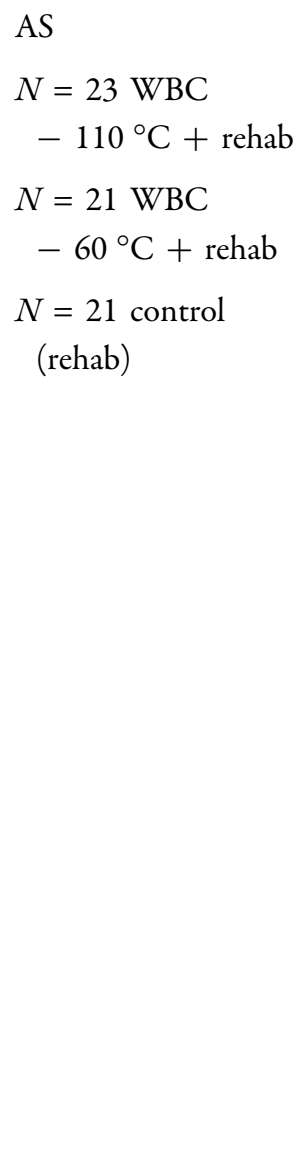 & $\begin{array}{l}\text { WBC at } \\
-110^{\circ} \mathrm{C} \text { or } \\
-60^{\circ} \mathrm{C} \text { for } \\
3 \text { min } 1 \times \text { a } \\
\text { day, } 6 \text { days }\end{array}$ & $\begin{array}{l}\text { Disease activity } \\
\text { (including pain): } \\
\text { BASDAI decreased } \\
\text { in }-110^{\circ} \mathrm{C} \\
(1.62),-60^{\circ} \mathrm{C} \\
(1.78) \text { and control } \\
(1.23) \text { groups; } \\
\text { significant } \\
\text { difference in } \\
\text { BASDAI b/w } \\
-110^{\circ} \mathrm{C} \text { and } \\
\text { control groups; no } \\
\text { significant } \\
\text { difference b/w } \\
\text { WBC at }-110^{\circ} \mathrm{C} \\
\text { and }-60{ }^{\circ} \mathrm{C} \text { after } \\
\text { therapy } \\
\text { Inflammation: IL-8 } \\
\text { decrease in all } \\
\text { groups, no changes } \\
\text { in IL-17 } \\
\text { Oxidative stress: No } \\
\text { change in TAS }\end{array}$ & None reported \\
\hline $\begin{array}{l}\text { Stanek et al., } \\
2018 \text { [32] }\end{array}$ & Randomized & $\begin{array}{l}\text { AS (male) } \\
N=16 \\
\text { WBC }+ \text { rehab } \\
N=16 \text { control } \\
\text { (rehab) }\end{array}$ & $\begin{array}{l}\text { WBC at } \\
-120{ }^{\circ} \mathrm{C} \text { for } \\
3 \text { min } 1 \times \text { a } \\
\text { day, } 8 \text { days }\end{array}$ & $\begin{array}{l}\text { Disease activity } \\
\text { (including pain): } \\
\text { BASDAI decreased } \\
\text { in both groups, } \\
\text { WBC group had } \\
\text { significantly greater } \\
\text { decrease in } \\
\text { BASDAI than } \\
\text { control ( } 2.14 \text { and } \\
\text { 0.74, respectively) } \\
\text { Inflammation: no } \\
\text { change in IL-6 }\end{array}$ & None reported \\
\hline
\end{tabular}


Table 1 continued

\begin{tabular}{|c|c|c|c|c|c|}
\hline Author, date & Study design & Study population & Intervention & Outcomes & Complications \\
\hline $\begin{array}{l}\text { Stanek et al., } \\
2018 \text { [24] }\end{array}$ & Randomized & $\begin{array}{l}\text { AS (male) } \\
N=16 \\
\text { WBC }+ \text { rehab } \\
N=16 \text { control } \\
\text { (rehab) }\end{array}$ & $\begin{array}{l}\text { WBC at } \\
-120^{\circ} \mathrm{C} \text { for } \\
3 \text { min } 1 \times \text { a } \\
\text { day, } 8 \text { days }\end{array}$ & $\begin{array}{l}\text { Disease activity } \\
\text { (including pain): } \\
\text { BASDAI decreased } \\
\text { in both groups, } \\
\text { WBC group had } \\
\text { significantly greater } \\
\text { decrease in } \\
\text { BASDAI than } \\
\text { control ( } 2.16 \text { and } \\
\text { 0.74, respectively) } \\
\text { Oxidative stress: } \\
\text { decrease in TOS } \\
\text { and OSI }\end{array}$ & None reported \\
\hline $\begin{array}{l}\text { Stanek et al., } \\
2011 \text { [31] }\end{array}$ & Randomized & $\begin{array}{l}\text { AS (male) } \\
N=16 \\
\text { WBC }+ \text { rehab } \\
N=16 \text { control } \\
\text { (rehab) }\end{array}$ & $\begin{array}{l}\text { WBC at } \\
-120^{\circ} \mathrm{C} \text { for } \\
3 \text { min } 1 \times \text { a } \\
\text { day, } 10 \text { sessions } \\
\text { in } 2 \text { weeks }\end{array}$ & $\begin{array}{l}\text { Pain reduction: WBC } \\
\text { and control groups } \\
\text { had a decrease in } \\
\text { VAS pain }(2.41 \mathrm{~cm} \\
\text { and } 0.91 \mathrm{~cm}), \text { but } \\
\text { the } \mathrm{WBC} \text { group } \\
\text { had a significantly } \\
\text { greater reduction in } \\
\text { pain than the } \\
\text { control }\end{array}$ & None reported \\
\hline
\end{tabular}

$R A$ rheumatoid arthritis; $W B C$ whole-body cryotherapy; VAS Visual Analogue Scale; $L C$ local cryotherapy; $b / w$ between; $w /$ with; w/o without; $G C$ glucocorticoids; $D A S$ Disease Activity Score; $R O M$ range of motion; $A S$ ankylosing spondylitis; BASDAI Bath Ankylosing Spondylitis Disease Activity Index; TOS Total Oxidative Status; TAS Total Antioxidant Status; OSI, Oxidative Stress Index

$-110^{\circ} \mathrm{C}+\mathrm{rehab}, \mathrm{WBC}$ at $-60^{\circ} \mathrm{C}+\mathrm{rehab}$, and control with just rehab), and it was noted that the group that underwent $\mathrm{WBC}$ at $-110^{\circ} \mathrm{C}$ along with physical therapy had a greater reduction in BASDAI compared to the group that just received physical therapy. No differences after therapy were found between WBC at $-110^{\circ} \mathrm{C}$ or $-60^{\circ} \mathrm{C}[33]$.

In patients with $\mathrm{RA}$ that had undergone WBC, pain scores also seem to trend downwards, although there are contradicting findings. Both Gizińska et al. and Sadura-Sieklucka et al. found that WBC $\left(-110{ }^{\circ} \mathrm{C}\right.$ and -120 to $-140^{\circ} \mathrm{C}$, respectively) along with physical rehabilitation on patients with RA had a significant decrease in pain VAS, but results were not significantly different compared to the control group that only received physical rehab $[12,29]$. Gizińska et al. also reported a decrease in disease activity (DAS28) and improvements in the 50-m walk test after WBC, showing increases in objective measurements of pain, but again those results were not significantly different than the control group. While these 
two studies suggest there is no additional benefit of adding cryotherapy to traditional rehab, it does not give insight into whether WBC as a standalone treatment would provide pain relief.

Straub et al. and Hirvonen et al. also looked at pain reduction in patients with RA after WBC at either $-110^{\circ} \mathrm{C}$ or $-60^{\circ} \mathrm{C}$. Both studies found a significant decrease in pain (VAS) in the group that received $\mathrm{WBC}$ at $-110^{\circ} \mathrm{C}$, but not in the group receiving $\mathrm{WBC}$ at $-60^{\circ} \mathrm{C}[16,34]$. However, the participants in the study by Hirvonen et al. also received physical rehab along with cryotherapy, but the study did not provide a control group that only received physical rehab. Additionally, a cross-over study in patients with inflammatory arthritis found that WBC produced a significantly greater reduction in pain (VAS) than the control group that did not receive WBC [35]. This study did not list the temperature of the WBC chamber, but the participants were instructed to stay $2 \mathrm{~min}$ in the chamber and the average skin temperature after WBC was $27^{\circ} \mathrm{C}$.

Local cryotherapy on patients with RA has also been investigated. Straub et al. found that LC did not provide any pain relief [16], but many others found significant improvements in pain following local application of cold $[13,34,36]$. One study that noted these improvements was conducted by Schlesinger et al., which required patients with RA to apply an ice pack for $20 \mathrm{~min}$ four times a day for a week. They found a significant decrease in pain (VAS) compared to the control group that did not receive LC [36]. In addition to pain relief (VAS) after LC, Jastrząbek et al. reported a significant increase in knee ROM along with improvements in the $50-\mathrm{m}$ walk test in patients with RA, supporting the subjective measurement of decreased pain (VAS) [13]. Hirvonen et al. also noted a decrease in pain (VAS) along with a decrease in disease activity as measured by DAS in patients with RA who received LC [34].

Lastly, a significant decrease in pain (VAS) was also found in patients with gouty arthritis following application of an ice pack, showing a large reduction of $7.75 \mathrm{~cm}$ [35], further supporting the use of LC in treating chronic pain caused by rheumatic diseases. Based on the literature discussed, cryotherapy in the form of both WBC and LC seem to have positive effects on the chronic pain and clinical activity of the associated disease, with temperatures below $-110{ }^{\circ} \mathrm{C}$ showing the most benefit.

\section{Degenerative Diseases}

Cryotherapy has also shown promise as an additional tool in chronic pain management in patients with degenerative diseases (Table 2). One very common degenerative disease that often arises with aging is osteoarthritis (OA). WBC has not been a major focus in studies involving patients with OA, but LC has been explored in previous studies and shows promising results. Aciksoz et al. noted a significant reduction in pain (VAS) at rest, during movement, and during sleep after a 2-week course of cold pack application for 20 min twice a day and continued to see an improvement 2 weeks after the course was completed. Additionally, the Nottingham Health Profile was conducted to measure a patients self-reported social, physical, and mental health. The participants reported significant improvements in the subsections of physical mobility, emotional reactions, pain, and energy [37], suggesting cryotherapy not only has benefits for pain, but a patient's overall quality of life as well.

Additionally in patients with OA, ice application three times a week for 3 weeks also showed a significant decrease in pain (VAS) compared to pre-application pain scores, and had a significantly greater reduction than the groups that received short-wave diathermy (heat) or placebo [38]. Cold cryocuff therapy showed similar results, with 20 min twice daily applications for 5 days showing a significant reduction in pain (VAS and knee injury and osteoarthritis outcome score, KOOS) in those with OA compared to the control group that was directed to rest [39]. Dantas et al. reporting conflicting results in which ice pack application once a day for $20 \mathrm{~min}$ for 4 consecutive days did not show significantly different results than the placebo group that received an "ice pack" filled with sand, although both groups did show a decrease in pain (VAS) [40]. 
Table 2 Degenerative diseases

\begin{tabular}{|c|c|c|c|c|c|}
\hline $\begin{array}{l}\text { Author, } \\
\text { date }\end{array}$ & Study design & Study population & Intervention & Outcomes & Complications \\
\hline $\begin{array}{c}\text { Aciksoz } \\
\text { et al., } \\
2017 \\
{[37]}\end{array}$ & Randomized & $\begin{array}{l}\text { OA } \\
N=32 \text { LC } \\
N=32 \text { heat } \\
N=32 \text { control }\end{array}$ & $\begin{array}{l}\text { LC (cold pack) } \\
\text { for } 20 \text { min } \\
2 \times \text { a day for } \\
3 \text { weeks }\end{array}$ & $\begin{array}{l}\text { Pain reduction: both the } \\
\text { cold and heat treatment } \\
\text { groups had a decrease in } \\
\text { pain VAS at rest, on } \\
\text { movement, and at sleep } \\
\text { Disease activity: cold } \\
\text { application showed } \\
\text { significant improvements } \\
\text { in physical mobility, } \\
\text { emotional reactions, } \\
\text { pain, and energy using } \\
\text { the Nottingham Health } \\
\text { Profile }\end{array}$ & $\begin{array}{l}43.7 \% \text { of } \\
\text { participants } \\
\text { noted some } \\
\text { discomfort }\end{array}$ \\
\hline $\begin{array}{l}\text { Nugraha } \\
\text { et al., } \\
2015 \\
{[41]}\end{array}$ & Randomized & $\begin{array}{l}\text { Chronic low back pain } \\
N=28 \mathrm{WBC}-67^{\circ} \mathrm{C} \\
N=29 \mathrm{WBC}-5^{\circ} \mathrm{C}\end{array}$ & $\begin{array}{l}\text { WBC at } \\
-67^{\circ} \mathrm{C} \text { or } \\
-5^{\circ} \mathrm{C} \text { for } \\
3 \text { min } 1 \times \text { a } \\
\text { day, } 10 \text { days }\end{array}$ & $\begin{array}{l}\text { Pain reduction: WBC at } \\
-67^{\circ} \mathrm{C} \text { reduced pain } \\
\text { VAS, pain perception } \\
\text { scale, and pain disability } \\
\text { index while WBC at } \\
-5^{\circ} \mathrm{C} \text { reduced pain } \\
\text { VAS and pain disability } \\
\text { index }\end{array}$ & None reported \\
\hline $\begin{array}{l}\text { Ma et al., } \\
\qquad 2013 \\
{[42]}\end{array}$ & Randomized & $\begin{array}{l}\text { Adhesive capsulitis } \\
N=15 \mathrm{WBC}+\text { rehab } \\
N=15 \text { control (rehab) }\end{array}$ & $\begin{array}{l}\text { WBC at } \\
-110^{\circ} \mathrm{C} \text { for } \\
4 \min 2 \times \text { a } \\
\text { day, } 3 \times \text { a } \\
\text { week for } \\
4 \text { weeks }\end{array}$ & $\begin{array}{l}\text { Pain reduction: WBC and } \\
\text { control group had a } \\
\text { decrease in pain VAS } \\
(3.5 \mathrm{~cm} \text { and } 2.3 \mathrm{~cm}, \\
\text { respectively), with a } \\
\text { significantly greater } \\
\text { decrease in the WBC } \\
\text { group than the control } \\
\text { group } \\
\text { ROM: WBC and control } \\
\text { group had an increase in } \\
\text { ROM with a } \\
\text { significantly greater } \\
\text { increase in the WBC } \\
\text { group than the control } \\
\text { group }\end{array}$ & None reported \\
\hline
\end{tabular}


Table 2 continued

\begin{tabular}{|c|c|c|c|c|c|}
\hline $\begin{array}{l}\text { Author, } \\
\text { date }\end{array}$ & Study design & Study population & Intervention & Outcomes & Complications \\
\hline $\begin{array}{l}\text { Denegar } \\
\text { et al., } \\
2010 \\
{[39]}\end{array}$ & $\begin{array}{l}\text { Randomized, } \\
\text { within } \\
\text { subject }\end{array}$ & $\begin{array}{l}\text { OA } \\
N=34,5 \text { different } \\
\text { treatments (heat } \\
\text { cryocuff, cold cryocuff, } \\
\text { contrast cryocuff, hot } \\
\text { pack, and no treatment } \\
\text { control-rest) }\end{array}$ & $\begin{array}{l}\text { LC (cryocuff) } \\
\text { for } 20 \text { min } \\
2 \times \text { a day, } \\
5 \text { days; no } \\
\text { temps reported }\end{array}$ & $\begin{array}{l}\text { Pain reduction: compared } \\
\text { to the control group, } \\
\text { cold cryocuff therapy } \\
\text { had a reduction in the } \\
\text { KOOS-pain and VAS } \\
\text { pain scores }\end{array}$ & None reported \\
\hline $\begin{array}{c}\text { Dantas } \\
\text { et al., } \\
2019 \\
{[40]}\end{array}$ & Randomized & $\begin{array}{l}\text { OA } \\
\begin{array}{l}N=30 \mathrm{LC} \\
N=30 \text { control (placebo } \\
\text { ice pack) }\end{array}\end{array}$ & $\begin{array}{l}\text { LC (ice pack) for } \\
20 \text { min } 1 \times \text { a } \\
\text { day, } 4 \text { days }\end{array}$ & $\begin{array}{l}\text { Pain reduction: both the } \\
\text { ice pack and placebo ice } \\
\text { pack filled with sand } \\
\text { had a decrease in pain } \\
\text { (VAS), but no } \\
\text { significant differences } \\
\text { between groups }\end{array}$ & None reported \\
\hline $\begin{array}{c}\text { Clarke } \\
\text { et al., } \\
1974 \\
{[38]}\end{array}$ & Randomized & $\begin{array}{l}\text { OA } \\
\begin{array}{l}N=17 \text { ice } \\
N=17 \text { short-wave } \\
\text { diathermy } \\
N=16 \text { placebo }\end{array}\end{array}$ & $\begin{array}{l}\text { LC (ice) } 3 \times \text { a } \\
\text { week for } \\
3 \text { weeks; no } \\
\text { temps or } \\
\text { length of } \\
\text { application } \\
\text { reported }\end{array}$ & $\begin{array}{l}\text { Pain reduction: at end of } \\
\text { treatment ( } 3 \text { weeks), ice } \\
\text { had a significant } \\
\text { decrease in pain } \\
\text { compared to short-wave } \\
\text { diathermy and placebo. } \\
\text { Significance lost at } \\
\text { 3-month follow-up, } \\
\text { where all treatments had } \\
\text { decrease in pain }\end{array}$ & None reported \\
\hline $\begin{array}{l}\text { García- } \\
\text { Espinoza } \\
\text { et al., } \\
2017 \\
{[43]}\end{array}$ & Prospective & $\begin{array}{l}\text { Myofascial pain syndrome } \\
N=20 \mathrm{WBC}\end{array}$ & $\begin{array}{l}\text { WBC at } \\
-160{ }^{\circ} \mathrm{C} \text { for } \\
3 \text { min } 1 \times \text { a } \\
\text { day, } 4 \times \text { a } \\
\text { week for } \\
5 \text { weeks }\end{array}$ & $\begin{array}{l}\text { Pain reduction: } \\
\text { Immediately after } \\
\text { WBC, there was a } \\
\text { decrease in VAS pain } \\
\text { and increase in pain } \\
\text { threshold } \\
\text { Inflammation: no changes } \\
\text { in IL-10 and TNF- } \alpha\end{array}$ & None reported \\
\hline
\end{tabular}

$O A$ osteoarthritis, $L C$ local cryotherapy, $W B C$ whole-body cryotherapy, $V A S$ Visual Analogue Scale, $R O M$ range of motion, KOOS Knee Injury and Osteoarthritis Outcome Score 
WBC, on the other hand, has been studied in other degenerative diseases including adhesive capsulitis, myofascial pain syndrome, musculoskeletal diseases, and chronic low back pain. WBC at both $-67^{\circ} \mathrm{C}$ and $-5^{\circ} \mathrm{C}$ reduced pain (VAS) and pain disability index in patients with chronic low back pain, and WBC at $-67{ }^{\circ} \mathrm{C}$ also reduced pain perception [41]. Similarly, Ma et al. reported a significant reduction in pain (VAS) after $\mathrm{WBC}$ at $-110^{\circ} \mathrm{C}$ in patients with adhesive capsulitis of the shoulder, with a significantly greater reduction in the WBC and rehab group compared to the control group just receiving rehab. Additionally, there was an increased range of motion of the affected shoulder with a significantly greater increase in those who received WBC [42].

Moreover, García-Espinoza et al. found a decrease in pain (VAS) in patients with myofascial pain syndrome of the trapezius who received $\mathrm{WBC}$ at $-160^{\circ} \mathrm{C}$, along with an increase in pain tolerance [43]. Both LC and WBC seem to be beneficial options and should be considered in the management of chronic pain due to degenerative disease. Interestingly, WBC may have positive effects starting at higher temperatures in degenerative diseases $\left(-5^{\circ} \mathrm{C}\right)$ compared to rheumatic diseases $\left(-110^{\circ} \mathrm{C}\right)$.

\section{Other}

Cryotherapy has also been explored as a method to alleviate chronic pain due to additional diseases such as chronic venous disease, fibromyalgia (FM), and multiple sclerosis (MS) (Table 3). It is difficult to draw a solidified conclusion on chronic venous disease and MS due to lack of studies in the literature. The one study we found on chronic venous disease, conducted by Kelechi et al., reported a reduction in both long-term (measured by Venous Insufficiency Epidemiological and Economic Study-Quality of Life/Symptoms, VEINESQOL/Sym) and short-term pain (measured by the Numeric Rating Scale, NRS) in the group that received cryocuff therapy as well as the placebo group that received a cotton-filled cuff, with no significant differences between groups
[44]. Since there were no differences between groups, it could be plausible that the compression from the cryocuff had an impact on pain rather than the cold therapy itself. In the one study on patients with MS, Miller et al. had the participants undergo $\mathrm{WBC}$ at $-110{ }^{\circ} \mathrm{C}$ to $-160^{\circ} \mathrm{C}$ and noted an increase in motor function and decrease in disease activity [45]. Motor function was measured by the Rivermead Motor Assessment and looked at gross, leg and trunk, and arm function and disease activity was measured by both the Expanded Disability Status Scale and the Multiple Sclerosis Impact Scale. These give an insight into the objective effects of cryotherapy, however subjective, quantitative pain scores were not reported.

There seems to be promising results for patients with $\mathrm{FM}$. In patients with $\mathrm{FM}$ that received $\mathrm{WBC}$, temperatures of $-196^{\circ} \mathrm{C}$, $-140{ }^{\circ} \mathrm{C}$ and $-110^{\circ} \mathrm{C}$ were shown to benefit patient pain. Rivera et al. reported a significant decrease in pain (VAS) in patients with FM as compared to the control group after receiving WBC at $-196^{\circ} \mathrm{C}$ [46]. Similarly, Bettoni et al. noted that patients that underwent WBC at $-140{ }^{\circ} \mathrm{C}$ had a significant reduction in pain (VAS). The control group also had a decrease in pain, but the group that received WBC had a significantly greater decrease in pain [47]. It was also found by Vitenet et al. that WBC at $-110{ }^{\circ} \mathrm{C}$ increased patients' self-rated quality of life as measured by the Medical Outcomes Study Short Form-36, which includes questions about disease impact on function, daily living, mental health, and pain [48]. However, a stand-alone, quantitative pain score was not one of the outcomes measured.

Additionally, LC on patients with FM has also been noted by Yilmaz and Kiyak to be of benefit. They reported a decrease in pain (VAS) up to $24 \mathrm{~h}$ after cold pack application for $10 \mathrm{~min}$ [49], further supporting the beneficial effect on cryotherapy on pain reduction in patients with FM. More quality studies are required in order to draw a strong conclusion on whether cryotherapy offers benefit to patients with chronic venous disease or MS, but the literature supports that cryotherapy can be useful in the management of the persistent pain accompanying FM. 
Table 3 Other

\begin{tabular}{|c|c|c|c|c|c|}
\hline $\begin{array}{l}\text { Author, } \\
\text { date }\end{array}$ & Study design & $\begin{array}{l}\text { Study } \\
\text { population }\end{array}$ & Intervention & Outcomes & Complications \\
\hline $\begin{array}{l}\text { Kelechi } \\
\text { et al., } \\
2018 \\
{[44]}\end{array}$ & Randomized & $\begin{array}{c}\text { Chronic } \\
\text { venous } \\
\text { disease } \\
N=138 \\
\text { cryocuff } \\
N=138 \\
\text { placebo } \\
\text { cuff }\end{array}$ & $\begin{array}{l}\text { LC (gel cryocuff) that } \\
\text { reduced skin temp by } \\
\text { avg of } 3{ }^{\circ} \mathrm{C} \text { for } \\
9 \text { months; } 1 \text { month } \\
\text { 30-min } 1 \times \text { a day; } \\
2-3 \text { months } 30 \text {-min } \\
3 \times \text { a week; } 4-6 \\
\text { months } 30 \text {-min } 1 \times \text { a } \\
\text { week, month 7-9 } \\
\text { 30-min whenever } \\
\text { needed }\end{array}$ & $\begin{array}{l}\text { Pain reduction: both } \\
\text { cryocuff and placebo } \\
\text { cuff had decrease in } \\
\text { short-term (NRS) and } \\
\text { long-term (VEINES- } \\
\text { QOL/Sym) pain, but } \\
\text { no differences between } \\
\text { groups }\end{array}$ & None reported \\
\hline $\begin{array}{l}\text { Bettoni } \\
\text { et al., } \\
2013 \\
{[47]}\end{array}$ & Randomized & $\begin{array}{l}\text { FM } \\
N=50 \\
\text { WBC } \\
N=50 \\
\text { control }\end{array}$ & $\begin{array}{l}\text { WBC at }-140{ }^{\circ} \mathrm{C} \text { for } \\
3 \text { min, } 15 \text { sessions in } \\
3 \text { weeks }\end{array}$ & $\begin{array}{l}\text { Pain reduction: both } \\
\text { WBC and control had } \\
\text { a decrease in pain } \\
\text { VAS, but WBC group } \\
\text { had a significantly } \\
\text { greater decrease }\end{array}$ & None reported \\
\hline $\begin{array}{l}\text { Rivera } \\
\text { et al., } \\
2018 \\
{[46]}\end{array}$ & $\begin{array}{l}\text { Randomized, } \\
\text { crossover }\end{array}$ & $\begin{array}{l}\text { FM } \\
N=60 \\
3 \text { weeks } \\
\text { WBC, } \\
3 \text { weeks } \\
\text { control } \\
\text { (rest) }\end{array}$ & $\begin{array}{l}\text { WBC at }-196^{\circ} \mathrm{C} \text { for } \\
3 \text { min, every other day } \\
\text { for } 3 \text { weeks }\end{array}$ & $\begin{array}{l}\text { Pain reduction: WBC } \\
\text { group had significantly } \\
\text { larger decrease in VAS } \\
\text { pain after } 3 \text { weeks } \\
\text { compared to control } \\
(3.0 \mathrm{~cm} \text { and } 0.3 \mathrm{~cm}, \\
\text { respectively) }\end{array}$ & $\begin{array}{l}\text { Heartbeat feeling in } \\
\text { whole body (1), } \\
\text { palpitations (1), sleep } \\
\text { difficulties (2), bowel } \\
\text { sounds and bloating } \\
\text { (1), muscle stiffness } \\
\text { (1), tremor (1), } \\
\text { headache (1) - all } \\
\text { minor and waning } \\
\text { after the first sessions }\end{array}$ \\
\hline $\begin{array}{l}\text { Vitenet } \\
\text { et al., } \\
2018 \\
{[48]}\end{array}$ & Randomized & $\begin{array}{l}\text { FM } \\
N=13 \\
\text { WBC } \\
N=11 \\
\text { control }\end{array}$ & $\begin{array}{l}\text { WBC at }-110^{\circ} \mathrm{C} \text { for } \\
3 \text { min, } 10 \text { sessions in } \\
8 \text { days }\end{array}$ & $\begin{array}{l}\text { Pain reduction: WBC } \\
\text { group had significant } \\
\text { improvement in self- } \\
\text { rated quality of life } \\
\text { (MOS SF-36), } \\
\text { including questions on } \\
\text { pain }\end{array}$ & None reported \\
\hline
\end{tabular}


Table 3 continued

\begin{tabular}{|c|c|c|c|c|c|}
\hline $\begin{array}{l}\text { Author, } \\
\text { date }\end{array}$ & Study design & $\begin{array}{l}\text { Study } \\
\text { population }\end{array}$ & Intervention & Outcomes & Complications \\
\hline $\begin{array}{l}\text { Yilmaz } \\
\text { and } \\
\text { Kiyak, } \\
2017 \\
{[49]}\end{array}$ & $\begin{array}{l}\text { One-group pre- } \\
\text { test/post-test } \\
\text { pre- } \\
\text { experimental } \\
\text { model }\end{array}$ & $\begin{array}{l}\mathrm{FM} \\
N=55 \\
\mathrm{LC}\end{array}$ & $\begin{array}{l}\text { LC }(\text { cold pack), } \\
1 \times \text { application for } \\
10 \text { min; no temp } \\
\text { reported }\end{array}$ & $\begin{array}{l}\text { Pain reduction: VAS } \\
\text { pain after LC } \\
\text { significantly lower at } \\
10 \mathrm{~min}(2.75 \mathrm{~cm}) \text {, } \\
1.5 \mathrm{~h}(2.45 \mathrm{~cm}) \text {, and } \\
24 \mathrm{~h}(3.36 \mathrm{~cm}) \\
\text { compared to pre-cold } \\
\text { application }(6.45 \mathrm{~cm})\end{array}$ & None reported \\
\hline $\begin{array}{l}\text { Miller } \\
\text { et al., } \\
2016 \\
{[45]}\end{array}$ & Case-control & $\begin{array}{l}\text { MS } \\
N=24 \\
\text { high- } \\
\text { fatigue } \\
\text { patients } \\
N=24 \\
\text { low- } \\
\text { fatigue } \\
\text { patients }\end{array}$ & $\begin{array}{l}\text { WBC at }-110^{\circ} \mathrm{C} \text { to } \\
-160^{\circ} \mathrm{C} \text { for } 3 \mathrm{~min}, \\
1 \times \text { a day for } 10 \text { days }\end{array}$ & $\begin{array}{l}\text { Disease activity: increases } \\
\text { in motor function in } \\
\text { all groups (Rivermead } \\
\text { Motor Assessment), } \\
\text { decreases in Expanded } \\
\text { Disability Status Scale } \\
\text { (EDSS) and Multiple } \\
\text { Sclerosis Impact Scale } \\
\text { (MSIS-29) }\end{array}$ & None reported \\
\hline
\end{tabular}

LC local cryotherapy, WBC whole-body cryotherapy, NRS Numeric Rating Scale, VEINES-QOL/Sym Venous Insufficiency Epidemiological and Economic Study-Quality of Life/Symptoms, FM fibromyalgia, VAS Visual Analogue Scale, MOS SF36 Medical Outcomes Study 36-item Short Form Survey Instrument, $M S$ multiple sclerosis, EDSS Expanded Disability Status Scale, MSIS-29 Multiple Sclerosis Impact Scale

\section{Adverse Effects}

Cryotherapy seems to be a fairly safe therapy with only mild reports of adverse effects found in the included studies. Some of the adverse effects noted in patients that received LC include respiratory infection, frost bite, joint or muscle pain, and discomfort [34, 37]. Some of the adverse effects noted in those that underwent WBC include headache, hypertension, dizziness, malaise, joint or muscle pain, nervousness, respiratory infection, long lasting freezing, urticaria, slight aggravation of symptoms in the beginning days of treatment, a heartbeat feeling throughout the whole body, palpitations, sleep difficulties, bowel sounds and bloating, muscle stiffness, and tremor
$[28,34,46]$. However, out of the 24 studies included, only four reported any adverse effects and most were short-lasting and mild. Careful selection of patients in the aforementioned studies likely limited complications.

\section{CONCLUSIONS}

Chronic pain is a crucial aspect in the management of many chronic diseases as it can have a profound effect on the function of the associated body parts and may significantly hinder a patient's daily life. Cryotherapy has been around and used for the management of chronic pain for decades, dating back to the time of Hippocrates and still being commonly 
prescribed by physicians and physical therapists today. While such a common practice, the actual effectiveness of cryotherapy in reducing chronic pain has remained unknown. In this paper, we describe evidence for the effectiveness of cryotherapy in alleviating chronic pain due to a variety of chronic diseases.

The mechanism behind this pain reduction is thought to occur through the reduction of inflammation and edema, oxidative stress, and nerve conduction velocity in pain fibers. In regard to patients with rheumatic diseases such as gouty arthritis, psoriatic arthritis, rheumatoid arthritis, and ankylosing spondylitis, cryotherapy shows promising results. Whole-body cryotherapy demonstrated a reduction in both pain and disease activity, with temperatures of at least $-110{ }^{\circ} \mathrm{C}$ having the best results. Results also indicate that local cryotherapy can be an effective therapy in providing pain relief in patients with these diseases.

The literature on degenerative diseases including osteoarthritis, chronic low back pain, musculoskeletal diseases, myofascial pain syndrome, and adhesive capsulitis show similar results. In patients with osteoarthritis, results suggest benefits from local cryotherapy in relieving pain but evidence on whole-body cryotherapy is lacking. On the other hand, whole-body cryotherapy on other degenerative diseases show promising results, with results on pain reduction starting at temperatures of $-5^{\circ} \mathrm{C}$ and continuing to temperatures of $-160^{\circ} \mathrm{C}$.

The studies included in the "Other" section included patients with chronic venous disease, fibromyalgia, and multiple sclerosis, and literature on these diseases was sparse other than fibromyalgia. The one study on chronic venous diseases found there was no effect of wholebody cryotherapy on pain, and the one study on multiple sclerosis suggested there was a pain reduction caused by whole-body cryotherapy, but the lack of studies on these two diseases make it hard to draw a solidified conclusion on cryotherapy's effectiveness of these diseases. The studies on fibromyalgia, on the other hand, suggest that both local and whole-body cryotherapy provide pain relief.
It is important to note, however, that there are some limitations in our study. We found there to be a lack of standardized studies, with studies differing on temperature, duration of application, and study length. Additionally, there is significant variability in use and practice types. This made homogenization of data across studies in a meta-analysis impossible. Second, some studies lacked a control group, and often cryotherapy was used in combination with a standard treatment such as pain medications or kinesiotherapy. Again, this made cross-study comparison difficult and it is difficult to elucidate the precise role of cryotherapy amongst other standard treatments.

In general, we noticed that as long as patients are screened and those with prior conditions such as cryoglobulinemia, Raynaud's disease, paroxysmal cold hemoglobinuria, peripheral vascular diseases, or insensate skin are advised not to use cryotherapy, cryotherapy is fairly safe with only mild and sparse side effects. Overall, evidence suggests that both non-local and local cryotherapy can be considered low-risk and easy treatment options to add in the management of chronic pain in carefully selected patients. Future research should focus on finding a more standardized application of cryotherapy, as well as include a wider array of chronic diseases associated with chronic pain. In addition, since chronic pain is persistent and long-lasting, future research should focus on the long-term effects of cryotherapy on chronic pain.

\section{ACKNOWLEDGEMENTS}

Funding. No funding or sponsorship was received for this study or publication of this article.

Authorship. All named authors meet the International Committee of Medical Journal Editors (ICMJE) criteria for authorship for this article, take responsibility for the integrity of the work as a whole, and have given their approval for this version to be published. 
Disclosures. Alaa Abd-Elsayed is a consultant for Medtronic, and Avanos. Carol Garcia, Jay Karri and Nicholas A. Zacharias have nothing to disclose.

Compliance with Ethics Guidelines. This article is based on previously conducted studies and does not contain any new studies with human participants or animals performed by any of the authors.

Open Access. This article is licensed under a Creative Commons Attribution-NonCommercial 4.0 International License, which permits any non-commercial use, sharing, adaptation, distribution and reproduction in any medium or format, as long as you give appropriate credit to the original author(s) and the source, provide a link to the Creative Commons licence, and indicate if changes were made. The images or other third party material in this article are included in the article's Creative Commons licence, unless indicated otherwise in a credit line to the material. If material is not included in the article's Creative Commons licence and your intended use is not permitted by statutory regulation or exceeds the permitted use, you will need to obtain permission directly from the copyright holder. To view a copy of this licence, visit http://creativecommons.org/licenses/by$\mathrm{nc} / 4.0 /$.

\section{REFERENCES}

1. Chanliongo PM. Cold (cryo) therapy. In: Lennard TA, Walkowski S, Singla AK, Vivian DG, editors. Pain procedures in clinical practice. Philadelphia: Elsevier; 2011. p. 555-8.

2. Bouzigon R, Grappe F, Ravier G, Dugue B. Wholeand partial-body cryostimulation/cryotherapy: current technologies and practical applications. J Therm Biol. 2016;61:67-81.

3. Hippocrates. Aphorisms. In: Jones WHS, Henderson J (eds). Hippocrates Volume IV, Heracleitus on the Universe. Cambridge: Harvard University Press; 1931, pp 97-222.

4. Floyer J. An inquiry into the right use and abuses of hot, cold, and temperate baths in England. London: Printed for R. Clavel at the Peacock, 1697.
5. The Magnetic and Cold Water Guide. American Historical Periodicals. June 1, 1846. https://go-galecom.ezproxy.library.wisc.edu/ps/navigateToIssue? volume $=1$ \&loadFormat $=$ page \&issueNumber $=1 \&$ use rGroupName=wisc_madison\&inPS=true\&mCode $=$ 063B\&prodId $=$ AAHP\&issueDate $=118460601$. Accessed 24 Aug 2020

6. Behrens BJ, Beinert H. Physical agents: theory and practice. 3rd ed. Philadelphia: F. A. Davis Company; 2014.

7. Stöckle U, Hoffmann R, Schütz M, Von Fournier C, Südkamp NP, Haas N. Fastest reduction of posttraumatic edema: continuous cryotherapy or intermittent impulse compression? Foot Ankle Int. 1997;18:432-8.

8. Deal DN, Tipton J, Rosencrance E, Curl WW, Smith TL. Ice reduces edema: a study of microvascular permeability in rats. J Bone Jt Surg Ser A. 2002;84: 1573-8.

9. Ho SSW, Coel MN, Kagawa R, Richardson AB. The effects of ice on blood flow and bone metabolism in knees. Am J Sports Med. 1994;22:537-40.

10. Parham P. The immune system. 4th ed. New York: Garland Science; 2014.

11. Ziemann E, Olek RA, Kujach S, et al. Five-day whole-body cryostimulation, blood inflammatory markers, and performance in high-ranking professional tennis players. J Athl Train. 2012;47:664-72.

12. Gizińska M, Rutkowski R, Romanowski W, Lewandowski J, Straburzyńska-Lupa A. Effects of wholebody cryotherapy in comparison with other physical modalities used with kinesitherapy in rheumatoid arthritis. Biomed Res Int. 2015;2015:1-7.

13. Jastrząbek R, Straburzyńska-Lupa A, Rutkowski R, Romanowski W. Effects of different local cryotherapies on systemic levels of TNF- $\alpha$, IL- 6 , and clinical parameters in active rheumatoid arthritis. Rheumatol Int. 2013;33:2053-60.

14. Lubkowska A, Szyguła Z, Chlubek D, Banfi G. The effect of prolonged whole-body cryostimulation treatment with different amounts of sessions on chosen pro-and anti-inflammatory cytokines levels in healthy men. Scand J Clin Lab Invest. 2011;71: 419-25.

15. Lubkowska A, Szygula Z, Klimek AJ, Torii M. Do sessions of cryostimulation have influence on white blood cell count, level of IL6 and total oxidative and antioxidative status in healthy men? Eur J Appl Physiol. 2010;109:67-72.

16. Straub RH, Pongratz G, Hirvonen H, Pohjolainen T, Mikkelsson M, Leirisalo-Repo M. Acute cold stress 
in rheumatoid arthritis inadequately activates stress responses and induces an increase of interleukin 6. Ann Rheum Dis. 2009;68:572-8.

17. Scheller J, Chalaris A, Schmidt-Arras D, Rose-John S. The pro- and anti-inflammatory properties of the cytokine interleukin-6. Biochim Biophys Acta Mol Cell Res. 2011;1813:878-88.

18. Pedersen BK. The anti-inflammatory effect of exercise: Its role in diabetes and cardiovascular disease control. Essays Biochem. 2006;42:105-17.

19. Herrera E, Sandoval MC, Camargo DM, Salvini TF. Motor and sensory nerve conduction are affected differently by ice pack, ice massage, and cold water immersion. Phys Ther. 2010;90:581-91.

20. Algafly AA, George KP. The effect of cryotherapy on nerve conduction velocity, pain threshold and pain tolerance. Br J Sports Med. 2007;41:365-9.

21. Srivastava A, Srivastava A. Oxidative stress-mediated human diseases. In: Maurya PK, Chandra P, editors. Oxidative stress: diagnostic methods and applications in medical science. Springer: Singapore; 2017. p. 141-51.

22. Stanek A, Sieroń-Stołtny K, Romuk E, et al. Wholebody cryostimulation as an effective method of reducing oxidative stress in healthy men. Adv Clin Exp Med. 2016;25:1281-91.

23. Miller E, Mrowicka M, Malinowska K, Żołyński K, Kędziora J. Effects of whole-body cryotherapy on total anti-oxidative status and activities of some antioxidative enzymes in blood of patients with multiple sclerosis-preliminary study. J Med Investig. 2010;57:168-73.

24. Stanek A, Cholewka A, Wielkoszyński T, Romuk E, Sieron A. Decreased oxidative stress in male patients with active phase ankylosing spondylitis who underwent whole-body cryotherapy in closed cryochamber. Oxid Med Cell Longev. 2018a;2018:1-9.

25. Stanek A, Romuk E, Wielkoszyński T, Bartuś S, Cieślar G, Cholewka A. Decreased lipid profile and oxidative stress in healthy subjects who underwent whole-body cryotherapy in closed cryochamber with subsequent kinesiotherapy. Oxid Med Cell Longev. 2019;2019:1-10.

26. Benny B, Grabois M, Chan K. Physical medicine techniques in pain management. In: Benzon HT, Rathmell JP, Wu CL, Turk DC, Argoff CE, Hurley RW, editors. Practical management of pain. Elsevier: Philadelphia; 2014. p. 629-41.

27. Hartrick CT. Special features of pain studies. In: Abd-Elsayed A, editor. Pain. Cham: Springer; 2019. p. 87-90.
28. Stanek A, Cholewka A, Gadula J, Drzazga Z, Sieron A, Sieron-Stoltny K. Can whole-body cryotherapy with subsequent kinesiotherapy procedures in closed type cryogenic chamber improve BASDAI, BASFI, and some spine mobility parameters and decrease pain intensity in patients with ankylosing spondylitis? Biomed Res Int. 2015;2015:1-11.

29. Sadura-Sieklucka T, Solłtysiuk B, Karlicka A, Sokolłowska B, Kontny E, Ksiezopolska-Orlłowska K. Effects of whole body cryotherapy in patients with rheumatoid arthritis considering immune parameters. Reumatologia. 2019;57:320-532.

30. Liberati A, Altman DG, Tetzlaff J, et al. The PRISMA statement for reporting systematic reviews and meta-analyses of studies that evaluate health care interventions: explanation and elaboration. PLoS Med. 2009;6:1-28.

31. Stanek A, Cholewka A, Cieślar G, Rosmus-Kuczia I, Drzazga Z, Sieron A. The assessment of the analgesic action of whole-body cryotherapy in patients with ankylosing spondylitis. Fizjoterapia Pol. 2011;11: 49-55.

32. Stanek A, Cholewka A, Wielkoszyński T, Romuk E, Sieron A. Whole-body cryotherapy decreases the levels of inflammatory, oxidative stress, and atherosclerosis plaque markers in male patients with active-phase ankylosing spondylitis in the absence of classical cardiovascular risk factors. Mediators Inflamm. 2018b;2018:1-11.

33. Straburzyńska-Lupa A, Kasprzak MP, Romanowski MW, et al. The effect of whole-body cryotherapy at different temperatures on proinflammatory cytokines, oxidative stress parameters, and disease activity in patients with ankylosing spondylitis. Oxid Med Cell Longev. 2018;2018:1-8.

34. Hirvonen HE, Mikkelson MK, Kautiainen $\mathrm{H}$, Pohjolainen TH, Leirsalo-Repo M. Effectiveness of different cryotherapies on pain and disease activity in active rheumatoid arthritis. A randomised single blinded controlled trial. Clin Exp Rheumatol. 2006;24:295-301.

35. Hinkka $H$, Väättänen $\mathrm{S}$, Ala-Peijari $\mathrm{S}$, Nummi T. Effects of cold mist shower on patients with inflammatory arthritis: a crossover controlled clinical trial. Scand J Rheumatol. 2017;46:206-9.

36. Schlesinger N, Detry MA, Holland BK, et al. Local ice therapy during bouts of acute gouty arthritis. J Rheumatol. 2002;29:331-4.

37. Aciksoz S, Akyuz A, Tunay S. The effect of self-administered superficial local hot and cold application methods on pain, functional status and quality of life in primary knee osteoarthritis patients. J Clin Nurs. 2017;26:5179-90. 
38. Clarke GR, Willis LA, Stenner L, Nichols PJR. Evaluation of physiotherapy in the treatment of osteoarthrosis of the knee. Rheumatology. 1974;13: 190-7.

39. Denegar CR, Dougherty DR, Friedman JE, et al. Preferences for heat, cold, or contrast in patients with knee osteoarthritis affect treatment response. Clin Interv Aging. 2010;5:199-206.

40. Dantas LO, Breda CC, da Silva Serrao PRM, et al. Short-term cryotherapy did not substantially reduce pain and had unclear effects on physical function and quality of life in people with knee osteoarthritis: a randomised trial. J Physiother. 2019;65: 215-21.

41. Nugraha B, Günther J-T, Rawert H, Siegert R, Gutenbrunner C. Effects of whole body cryochamber therapy on pain in patients with chronic low back pain: a prospective double blind randomised controlled trial. Eur J Phys Rehabil Med. 2015;51:143-8.

42. Ma SY, Je HD, Jeong JH, Kim HY, Kim HD. Effects of whole-body cryotherapy in the management of adhesive capsulitis of the shoulder. Arch Phys Med Rehabil. 2013;94:9-16.

43. García-Espinoza ÓA, Salas-Fraire Ó, Flores-Garza PP, Salas-Longoria K, Valadez-Lira JA. Analgesic effect of whole body cryotherapy in patients with trapezius myofascial pain syndrome: a longitudinal, non-blinded, experimental study. Med Univ. 2017;19:115-22.
44. Kelechi TJ, Mueller M, Madisetti M, Prentice MA, Dooley MJ. Effectiveness of cooling therapy (cryotherapy) on leg pain and self-efficacy in patients with chronic venous disease: a randomized controlled trial. Int J Nurs Stud. 2018;86:1-10.

45. Miller E, Kostka J, Włodarczyk T, Dugué B. Wholebody cryostimulation (cryotherapy) provides benefits for fatigue and functional status in multiple sclerosis patients. A case-control study. Acta Neurol Scand. 2016;134:420-6.

46. Rivera J, Tercero MJ, Salas JS, Gimeno JH, Alejo JS. The effect of cryotherapy on fibromyalgia: a randomised clinical trial carried out in a cryosauna cabin. Rheumatol Int. 2018;38:2243-50.

47. Bettoni L, Bonomi FG, Zani V, et al. Effects of 15 consecutive cryotherapy sessions on the clinical output of fibromyalgic patients. Clin Rheumatol. 2013;32:1337-45.

48. Vitenet M, Tubez F, Marreiro A, et al. Effect of whole body cryotherapy interventions on healthrelated quality of life in fibromyalgia patients: a randomized controlled trial. Complement Ther Med. 2018;36:6-8.

49. Yilmaz N, Kiyak E. The effects of local cold application on fibromyalgia pain. Int J Rheum Dis. 2017;20:929-34. 